\title{
Long-term changes in lowland calcareous grassland plots using Tephroseris integrifolia subsp. integrifolia as an indicator species
}

\author{
P. A. Stroh • O. L. Pescott $\cdot$ J. O. Mountford
}

Received: 3 April 2017/Accepted: 1 September 2017/Published online: 6 September 2017

(C) The Author(s) 2017. This article is an open access publication

\begin{abstract}
We investigated the changes to calcareous grassland plots within protected sites, and whether Tephroseris integrifolia subsp. integrifolia can act as a useful indicator species for re-visitation studies within vegetation predicted to remain relatively stable. Twenty-two plots located across lowland England and all formerly containing $T$. integrifolia were resurveyed following the methodology used in the original survey undertaken in the 1960s. Pseudoturnover and between-observer bias were minimised by sampling replicate quadrats at each fixed plot using a single surveyor and at a similar time of year as the original survey. Qualitative details concerning grazing management were obtained for all sites. In contrast to other long-term re-visitation studies, all our study plots were intact and retained diverse, herb-rich
\end{abstract}

Communicated by Wayne Polley.

P. A. Stroh $(\bowtie)$

Botanical Society of Britain and Ireland, Cambridge

University Botanic Garden, 1 Brookside,

Cambridge CB2 1JE, UK

e-mail: peter.stroh@bsbi.org

O. L. Pescott · J. O. Mountford

NERC Centre for Ecology and Hydrology, Maclean

Building, Benson Lane, Crowmarsh Gifford, Wallingford,

Oxfordshire OX10 8BB, UK

e-mail: olipes@ceh.ac.uk

J. O. Mountford

e-mail: om@ceh.ac.uk vegetation, demonstrating the value of site protection. However, there were clear shifts in vegetation composition, most notably where $T$. integrifolia was absent, as shown by an increase in Ellenberg fertility and moisture signifying nutrient enrichment, and a decrease in the cover of low-growing, light-demanding specialists, with a change likely to be associated predominantly with grazing management. Whereas in the mid-20th century the greatest threat to calcareous grassland was habitat loss, undergrazing or temporary neglect now appears to pose the principal threat. Distinctive species such as T. integrifolia with marked sensitivity to habitat change provide a potentially useful tool for rapid assessment and monitoring of site quality. Focusing monitoring on such species allows non-expert observers to recognise the early stages of habitat degradation, providing, in effect, a "health check" on individual sites and groups of sites.

Keywords Livestock grazing - Re-survey · Bromopsis erecta . Vegetation change · Grassland management $\cdot$ Site of Special Scientific Interest (SSSI)

Nomenclature: Stace (2010) for plants.

\section{Introduction}

Calcareous grasslands are one of the most species-rich communities of temperate Europe (Wells 1969; Poschlod and Wallis DeVries 2002), but over the past 
60 years there has been a well-documented decline in the extent and quality of such grasslands across northwestern Europe (Fuller 1987; Willems 1990; Van Dijk 1991; Critchley et al. 2003) and as a consequence a decline in distribution for many calcicolous species (Preston et al. 2002; Polus et al. 2007). Historical loss has resulted in fragmentation (Fischer and Stöcklin 1997; Hodgson et al. 2005), with the result that surviving pieces of grassland are often logistically more difficult to graze and therefore more susceptible to abandonment or changes to grazing pressure that frequently result in an impoverished flora and fauna (Keymer and Leach 1990; Bobbink and Willems 1987; Willems et al. 1993; Kahmen et al. 2002; Adriaens et al. 2006). For example, across Europe, half of all threatened butterfly species occur on calcareous grassland (Van Swaay 2002). In England, twenty percent of all threatened vascular plant species are associated with calcareous grassland, and threatened taxa overall have a significantly greater association with open habitat on highly basic soils than non-threatened species (Stroh et al. 2014).

The availability of historical field survey data can help us understand better the reasons behind the decline (or stability, or expansion) of the population of an individual species and can also be a valuable resource for investigating broader vegetation and environmental trends. For example, a survey of Pulsatilla vulgaris sites in lowland England undertaken by Wells (1968) and repeated by Walker and Pinches (2011) recorded a decline in the distribution of $P$. vulgaris correlated with reduced grazing at sites previously supporting short, herb-rich swards. Van den Berg et al. (2011) re-surveyed permanent quadrat data from the early 1990s to understand better the effects of atmospheric nitrogen $(\mathrm{N})$ deposition on species-rich calcareous grassland sites, finding significant associations with high deposition and changes in Shannon diversity, evenness and a decline in the frequency of characteristic species. Bennie et al. (2006) re-visited calcareous grassland plots first surveyed in the early 1950s, finding that although there was a general reduction in species richness and a shift to more mesotrophic vegetation, plots located on steep, south-facing slopes with shallow rendzina soils were more resilient to the spread of competitive species compared with communities of deeper soils, due to phosphorus limitation and an increased frequency and magnitude of drought events. Pykälä et al.
(2005) reported similar results, with greater species richness maintained on sites with greater solar radiation.

In our study, we aimed to assess changes in chalk grassland vegetation by re-visiting vegetation plots located on steep and shallow soils, first recorded in the mid-1960s during a comprehensive survey of calcareous grassland across lowland England coordinated by T.C.E. Wells, the UK Nature Conservancy's first Grassland Ecologist (Farrell 2009). The results of this survey led to the designation and protection as Sites of Special Scientific Interest (SSSI) or National Nature Reserves (NNRs) for all but two of the locations we revisited. Plots selected for our re-survey all contained Field Fleawort (Tephroseris integrifolia subsp. integrifolia) in the original survey. This species is a longlived perennial hemicryptophyte that favours warm, dry, steep, south-facing sites on shallow and infertile rendzina soils high in calcium carbonate and deficient in nitrate and phosphate (Smith 1979). Extant plants die back by early autumn, but overwinter as cottony buds at ground level, with new leaves formed from these in late winter (Stroh 2016). Populations can be long-lived, with Widén (1987) calculating an average half-life of an individual at ca. 40 years in grazed grassland, although in lightly grazed, semi-shaded conditions the half-life was just 7 years. The primary means of reproduction is by seed, which are shortlived in the soil (Widén 1987). Seedling survival can be limited by drought, overgrazing in the summer months, undergrazing leading to shaded conditions and by browsing from snails, slugs and woodlice (Fenner 1975; Smith 1979). An extended period of neglect or undergrazing is therefore likely to result in the loss of a population, even if an appropriate grazing regime is then restored (Walker et al. 2017).

All these factors combine to make $T$. integrifolia a useful indicator species for targeted re-visitation studies that aim to assess long-term changes to species richness, diversity and composition within fixed plots at locations that are predicted to remain relatively stable, particularly if a suitably open and short sward has been maintained by prescriptive grazing regimes recommended for SSSI management (JNCC 2004). 


\section{Methods}

The original survey

Wells and colleagues visited a large swathe of the species-rich chalk and Oolite of southern and southeastern England between 1964 and 1967 (henceforth known as the "original survey"). They recorded all vascular plants within one (occasionally two or three) $1 \times 1 \mathrm{~m}$ quadrat randomly placed within representative $10 \times 10 \mathrm{~m}\left(100 \mathrm{~m}^{2}\right)$ plots at each site. Where multiple quadrats were recorded, only averages from across these quadrats were available. A grid reference and site description was documented for each plot, and a map illustrating the placement of the plot was sometimes drawn to aid relocation. Wooden marker posts were positioned at a few sites, but no plots were fenced, so allowing the grassland to be grazed or managed in the usual way. The data from this original survey are held at the Centre for Ecology and Hydrology, Wallingford, UK.

\section{The re-survey}

In June 2014 and June 2016, twenty-two plots across 14 sites were re-surveyed within the counties of Bedfordshire, Hertfordshire and Wiltshire (henceforth referred to as the "re-survey"; Fig. 1). We chose a sub-selection of plots from the original survey, with selection determined by the presence of T. integrifolia in the original quadrats. Without exception, these plots were originally located on steep, south- or southwestfacing slopes over thin chalk soils. Plots were relocated using an Ordnance Survey map of the area, a hand-held GPS unit, and the original 100-m grid reference. Descriptive notes and location maps from the original survey were also used for relocation, as were the physical characteristics of the site (e.g. slope, aspect) together with the surveyor's knowledge of the ecological requirements and preferred habitat of $T$. integrifolia. Once relocated, plots were first walked over and subjectively assessed to ensure that they were still recognisably unimproved or semi-improved calcareous grassland, although the re-survey found no plots that needed to be excluded on this basis. The plots were then searched meticulously for the presence of T. integrifolia.

To reduce the potential for subjectivity and pseudoturnover in our re-survey, five randomly placed
$1 \times 1 \mathrm{~m}$ replicate quadrats, stratified to ensure that T. integrifolia was included, if present, were sampled within each of the 22 plots surveyed; cover values of all vascular plants were recorded in each quadrat, along with sward height, the cover of graminoids and herbs, and the percentage of bare ground. The resurvey was undertaken by a single surveyor (PAS) to eliminate between-observer variation, and sites were visited at a similar time of year as the original survey, coinciding with the flowering of $T$. integrifolia. Revisitation surveys need to use a comparable methodology to minimise pseudo-turnover-the possibility of a species being incorrectly assigned as absent or present in the new survey if new and old records were not taken at the same location-particularly as time increases between the original and the new survey (Fischer and Stöcklin 1997). Ross et al. (2010) tested the efficacy of phytosociological re-visitation studies for the interpretation of vegetation change, assessing the potential for pseudo-turnover when undertaking a re-survey of upland vegetation plots used to classify plant communities of the Scottish Highlands. Their recommendations, followed here, included the recording of replicate plots in stands of homogenous vegetation within the potential area of the original plot to enable an assessment of real temporal change versus false change arising from spatial heterogeneity, thus allowing interpretations of change to be stated with more confidence.

The specifics of the current and past grazing regime (e.g. timing, stocking rate) for each of the sites revisited was sought, and in most cases sufficient information, though largely qualitative, was provided by landowners and land managers.

Nomenclature was standardised for the original survey and re-survey, and follows Stace (2010).

\section{Statistical analysis}

The original survey recorded species using the Domin scale as a measure of abundance. These cover values were converted to percentage covers using the Currall transformation (Currall 1987) so that all data were on a linear scale for analysis. Changes in species composition within fixed grassland plots since the first survey were analysed in relation to species richness and the Shannon-Wiener diversity index $\left(H^{\prime}\right)$. The extent to which the vegetation was dominated by a few species (evenness, $J$ ) was calculated by dividing $\mathrm{H}^{\prime}$ by the 
Fig. 1 Site map of study plots (black dots) re-visited in lowland England. Three counties are mapped: South Wiltshire (black outline), Bedfordshire (red outline) and Hertfordshire (blue outline). (Color figure online)

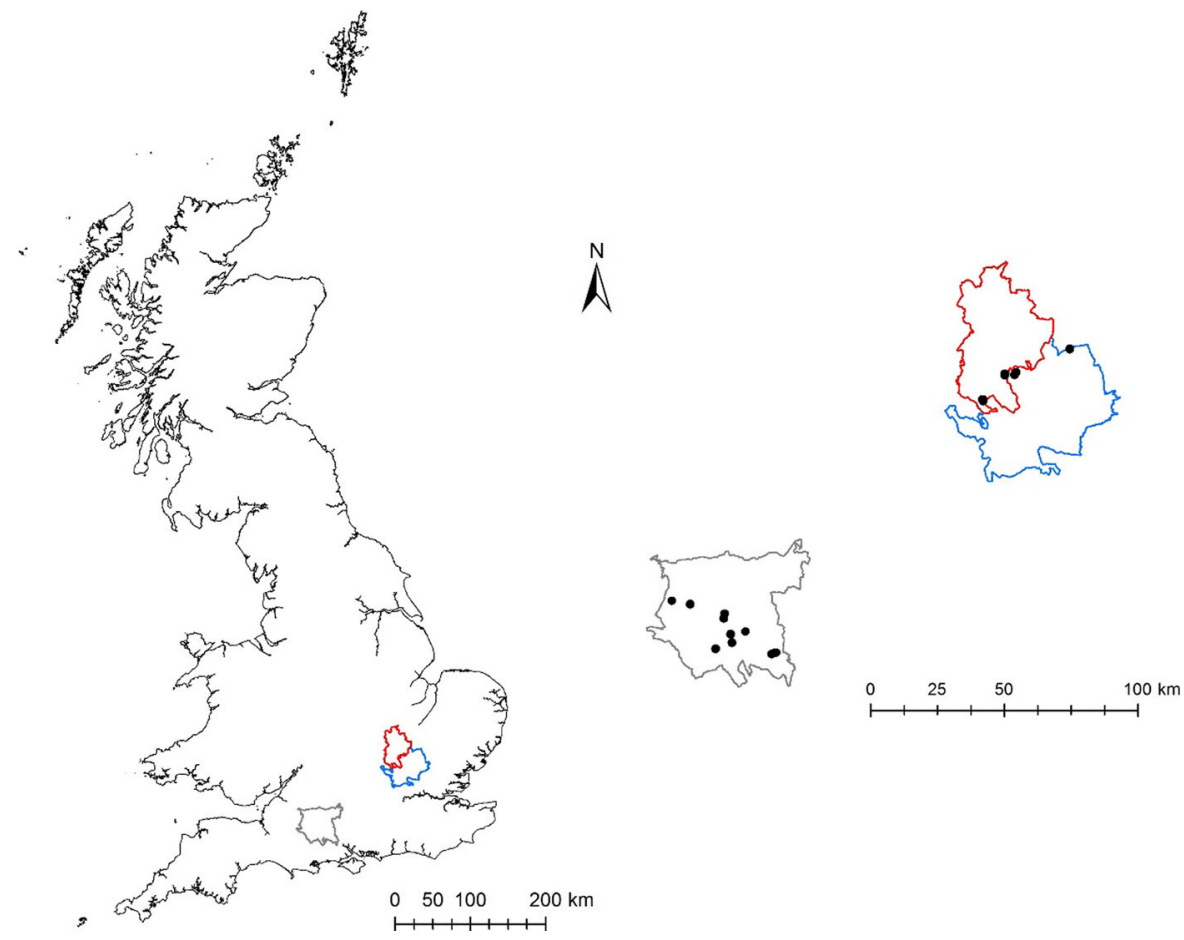

base $_{10}$ logarithm of the total number of species in the sample. Changes over time in relation to the presence or absence of $T$. integrifolia in permanent plots for three subsets (T. integrifolia present in 1967, absent in 2014/2016; T. integrifolia present in 2014/2016, absent in 2014/2016; T. integrifolia present in both 1967 and 2014/2016) were analysed. Where the same plot was compared between the two surveys, paired $t$ tests were used; where there was no matching between plots (the comparison between plots which had retained and lost Tephroseris in 2014/2016), a 2-sample $t$ test was used. Measures analysed between these sets of plots were the abundance of common species (present in $\geq 30 \%$ of quadrats) and Ellenberg indicator values (following Hill et al. 2004) for light (L), moisture $(\mathrm{F})$, reaction $(\mathrm{R})$ and nitrogen $(\mathrm{N})$. Ellenberg values were cover-weighted, and for the re-survey data the cover-weighted values for each of the five quadrats within a plot were averaged to produce a single value.

The potential for pseudo-turnover due to relocation uncertainty combined with fine-scale spatial heterogeneity was tested by comparing within-stand variation in the re-survey with long-term temporal change in composition. This was done by calculating a dissimilarity matrix of Bray-Curtis distances between paired comparisons of the original and each of the re- surveyed quadrats within a plot, and between all possible comparisons of the re-surveyed quadrats (following the protocol of Ross et al. 2010), also within plots. The average plot values for these two sets of (square-rooted) distances were then compared visually using boxplots and through estimates of the 95\% confidence intervals of the medians (Ross et al. 2010). Note that this approach to pseudo-turnover produces a heuristic measure of its likelihood, rather than a certain assessment of its absence; however, the combination of this approach with high-quality maps and notes from an original survey, and expert surveyor assessment of plant community type and homogeneity, should lead to increased confidence in assessments of temporal change.

\section{Results}

Testing for pseudo-turnover

Across all plots, the average Bray-Curtis distances between the quadrats of the two surveys were consistently higher than those within the re-survey (Fig. 2). Estimates of the $95 \%$ confidence intervals of the medians of these two sets of distances were clearly 


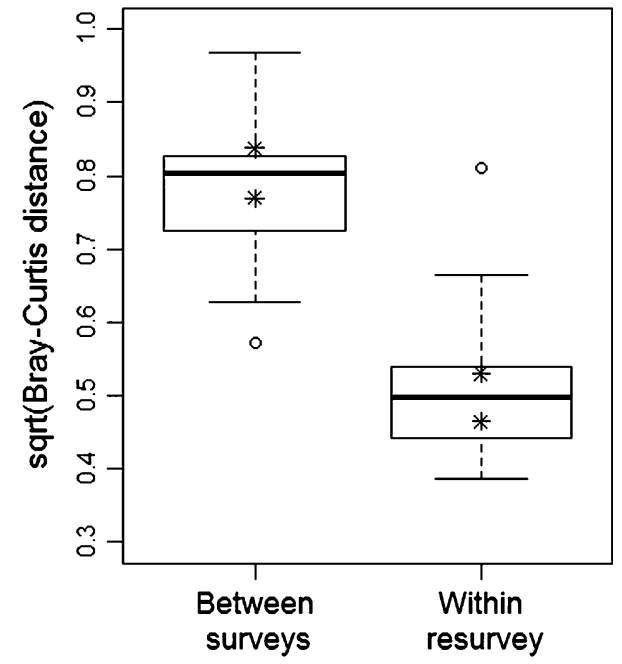

Fig. 2 Boxplots of the between-quadrat Bray-Curtis distances for each plot, both between surveys and within the re-survey. Horizontal thick black lines indicate median values; stars indicate the estimated $95 \%$ confidence intervals of the medians

separated (starred estimates, Fig. 2), giving strong support to a hypothesis of real temporal change between the two surveys, as compared to artefactual change due to within-plot spatial heterogeneity and relocation error.

Changes in vegetation composition at sites with the absence of Tephroseris

Tephroseris integrifolia was not re-recorded in 10 of the 22 plots. Where $T$. integrifolia was absent, species richness, diversity and evenness remained relatively constant across the two surveys, but there was a trend towards a coarser sward, with a significant increase in cover for Bromopsis erecta, Dactylis glomerata and Carex flacca, as well as a spread of more mesotrophic species such as Centaurea nigra, Ranunculus bulbosus, Taraxacum sp. and other rather coarser species of chalk swards such as Avenula pubescens, Galium verum and Poterium sanguisorba (Table 1). Declines were pronounced in semi-rosette species (e.g. Campanula rotundifolia, Scabiosa columbaria) and for lower-growing herbs generally. These results are reflected in elevated Ellenberg values since the original survey for moisture and nitrogen, and a decrease in Ellenberg values for reaction and light (Fig. 3).

A comparison of 2014/2016 re-survey data only also revealed clear differences between sites where $T$. integrifolia has persisted and where it has been lost. The extant Tephroseris sites have a higher cover of species that are light demanding, indicating greater illumination at soil level, as well as species typical of higher $\mathrm{pH}$ soils (Fig. 4). Vegetation with T. integrifolia also has a strong representation of low-growing chamaephytes (e.g. Helianthemum nummularium, Hippocrepis comosa, Thymus polytrichus) and semirosette or low-growing hemicryptophytes (e.g. Koeleria macrantha, Polygala vulgaris). In contrast, sites where the Tephroseris was absent had a composition significantly richer in species of moister, more fertile conditions, had a grassier sward and a greater cover and frequency of mesotrophic species (e.g. Galium verum, Plantago lanceolata).

Changes in vegetation composition for sites retaining Tephroseris

Tephroseris integrifolia was refound in 12 of the 22 plots in 2014/2016. In contrast to sites that had lost $T$. integrifolia, the vegetation at sites retaining $T$. integrifolia had undergone no significant change in overall floristic composition as reflected in the Ellenberg values (Fig. 5) and had a slightly increased richness and diversity. At many of these plots, nationally rare or threatened species were recorded as associates with $T$. integrifolia (e.g. Gentianella anglica, Hypochaeris maculata, Neotinea ustulata). There were, however, signals of change, with similar if less pronounced trends for individual species when compared with the changes experienced in the vegetation generally (Table 1). Notably, at sites where $T$. integrifolia was refound, Bromopsis erecta, Carex flacca, Poterium sanguisorba and Ranunculus bulbosus had increased significantly in cover since the original survey, and there were declines overall in the cover of some rosette and semi-rosette species, as well as some low-growing or light-demanding species such as Carex caryophyllea and Scabiosa columbaria.

\section{Grazing management}

Annual quantitative records for stocking densities at all but one site were either not kept or not obtainable. However, general qualitative information on current and past management, including local knowledge concerning grazing levels, was available for most sites. In broad terms, sites that retained $T$. integrifolia 
Table 1 Species present in $>30 \%$ of quadrats

\begin{tabular}{|c|c|c|c|c|c|c|c|c|c|}
\hline & \multicolumn{2}{|c|}{$\begin{array}{l}\text { Teph. present/ } \\
\text { absent }\end{array}$} & \multirow[t]{2}{*}{$T$} & \multicolumn{2}{|c|}{$\begin{array}{l}\text { Teph. present/ } \\
\text { absent }\end{array}$} & \multirow[t]{2}{*}{$T$} & \multicolumn{2}{|c|}{$\begin{array}{l}\text { Teph. present/ } \\
\text { present }\end{array}$} & \multirow[t]{2}{*}{$T$} \\
\hline & $1967 \mathrm{p}$ & $2016 \mathrm{a}$ & & $2016 p$ & $2016 \mathrm{a}$ & & $1967 p$ & $2016 p$ & \\
\hline \multicolumn{10}{|l|}{ (i) Cover-weighted indicator values } \\
\hline Ellenberg light (L) & 7.4 & 7.2 & $-4.6 * * *$ & 7.4 & 7.2 & $-3.7 * * *$ & 7.4 & 7.4 & -0.1 \\
\hline Ellenberg moisture $(\mathrm{F})$ & 4.2 & 4.5 & $5.2 * * *$ & 4.2 & 4.5 & $5.0 * * *$ & 4.2 & 4.2 & -0.7 \\
\hline Ellenberg reaction $(\mathrm{R})$ & 6.9 & 6.7 & $-2.6^{* *}$ & 6.9 & 6.7 & $-2.9 * *$ & 6.9 & 6.8 & 0.3 \\
\hline Ellenberg nitrogen $(\mathrm{N})$ & 2.9 & 3.4 & $4.2 * * *$ & 2.9 & 3.4 & $3.9 * * *$ & 2.9 & 2.8 & 0.2 \\
\hline \multicolumn{10}{|l|}{ (ii) Composition } \\
\hline Average number of species & 30.0 & 30.0 & $<0.1$ & 32.9 & 30.0 & -1.5 & 30.0 & 33.0 & 0.9 \\
\hline Diversity (Shannon) & 2.4 & 2.6 & 1.3 & 2.6 & 2.6 & -0.2 & 2.4 & 2.6 & 1.5 \\
\hline Evenness (Shannon/log10 diversity) & 1.6 & 1.8 & 1.7 & 1.7 & 1.8 & 0.6 & 1.6 & 1.7 & 1.2 \\
\hline \multicolumn{10}{|l|}{ (iii) $\%$ cover of common species } \\
\hline Asperula cynanchica & 3.4 & 2.1 & -1.2 & 4.6 & 2.1 & -1.3 & 3.4 & 4.6 & 0.8 \\
\hline Avenula pratensis & 9.3 & 9.8 & 0.2 & 9.2 & 9.8 & 0.1 & 9.3 & 9.2 & -0.2 \\
\hline Avenula pubescens & 1.7 & 8.9 & $4.1 * * *$ & 1.4 & 8.9 & $2.7 * *$ & 1.7 & 1.4 & -0.3 \\
\hline Briza media & 9.3 & 13.1 & 1.4 & 15.6 & 13.1 & -1.0 & 9.3 & 15.6 & $3.1 * *$ \\
\hline Bromopsis erecta & 11.9 & 32.2 & $3.4^{*}$ & 33.1 & 32.2 & -0.2 & 11.9 & 33.1 & $4.3 * * *$ \\
\hline Campanula glomerata & 1.4 & $<0.1$ & $-2.1 *$ & 1.0 & $<0.1$ & $-2.4^{*}$ & 1.4 & 5.4 & $3.0 * *$ \\
\hline Campanula rotundifolia & 3.5 & 0.1 & $-3.5^{* *}$ & 2.6 & 0.1 & $-4.2 * * *$ & 3.5 & 2.6 & -1.0 \\
\hline Carex caryophyllea & 5.7 & 0.1 & $-3.1 * *$ & 2.2 & 0.1 & $-3.2 * *$ & 5.7 & 2.2 & $-2.1 *$ \\
\hline Carex flacca & 13.4 & 19.4 & $2.1^{*}$ & 23.7 & 19.4 & -1.2 & 13.4 & 23.7 & $5.6 * * *$ \\
\hline Carlina vulgaris & 1.4 & 0.1 & $-2.4^{*}$ & 0.9 & 0.1 & -1.9 & 1.4 & 0.9 & -0.9 \\
\hline Centaurea nigra & 3.5 & 5.5 & 1.0 & 8.5 & 5.5 & -1.4 & 3.5 & 8.5 & $2.7 * *$ \\
\hline Cirsium acaule & 11.9 & 12.1 & 0.1 & 12.4 & 12.1 & -0.1 & 11.9 & 12.4 & 0.2 \\
\hline Crataegus monogyna & 0.6 & 1.5 & 1.3 & 0.6 & 1.5 & 1.2 & 0.6 & 0.6 & -0.1 \\
\hline Dactylis glomerata & 2.3 & 7.5 & $2.3^{*}$ & 0.3 & 7.5 & $3.3^{* *}$ & 2.3 & 0.3 & -1.3 \\
\hline Festuca ovina agg. & 31.4 & 26.4 & -1.2 & 25.4 & 26.4 & 0.7 & 31.4 & 25.4 & -1.5 \\
\hline Filipendula vulgaris & 2.4 & 4.1 & 0.9 & 7.0 & 4.1 & -1.1 & 2.4 & 7.0 & $2.4^{*}$ \\
\hline Galium verum & 1.7 & 8.1 & $4.0 * * *$ & 1.2 & 8.1 & $3.9 * * *$ & 1.7 & 1.2 & -0.5 \\
\hline Helianthemum nummularium & 5.8 & 7.5 & 0.6 & 9.5 & 7.5 & -0.5 & 5.8 & 9.5 & 1.6 \\
\hline Hippocrepis comosa & 6.7 & 8.3 & 0.5 & 10.7 & 8.3 & -0.6 & 6.7 & 3.2 & 0.6 \\
\hline Koeleria macrantha & 7.1 & 2.0 & $-3.3 * *$ & 5.5 & 2.0 & $-3.0 * *$ & 7.1 & 5.5 & -1.1 \\
\hline Leontodon hispidus & 8.4 & 12.3 & 1.5 & 3.3 & 12.3 & $3.3^{* *}$ & 8.4 & 3.3 & $-2.7 * *$ \\
\hline Leucanthemum vulgare & 1.9 & 4.0 & 1.5 & 1.8 & 4.0 & 1.3 & 1.9 & 1.8 & -0.2 \\
\hline Linum catharticum & 2.2 & 4.4 & $2.2 *$ & 8.7 & 4.4 & $-3.1 * *$ & 2.2 & 8.7 & $7.1 * * *$ \\
\hline Lotus corniculatus & 6.8 & 9.2 & 1.1 & 7.4 & 9.2 & 1.0 & 6.8 & 7.4 & 0.3 \\
\hline Medicago lupulina & 2.3 & 1.1 & -0.7 & 0.5 & 1.1 & 1.0 & 2.3 & 0.5 & -1.2 \\
\hline Pilosella officinarum & 4.5 & 4.3 & -0.1 & 5.9 & 4.3 & -0.7 & 4.5 & 5.9 & 1.0 \\
\hline Pimpinella saxifraga & 3.8 & 1.1 & $-2.2 *$ & 0.9 & 1.1 & 0.5 & 3.8 & 0.9 & $-2.6^{* *}$ \\
\hline Plantago lanceolata & 10.7 & 10.9 & 0.1 & 5.0 & 10.9 & $3.3^{* *}$ & 10.7 & 5.0 & $-3.6^{* *}$ \\
\hline Plantago media & 5.8 & 6.2 & 0.2 & 7.7 & 6.2 & -0.6 & 5.8 & 7.7 & 0.9 \\
\hline Polygala calcarea & 2.9 & 3.8 & 1.2 & 4.9 & 3.8 & -0.4 & 2.9 & 4.9 & 1.6 \\
\hline Polygala vulgaris & 1.3 & 0.7 & -0.6 & 4.5 & 0.7 & $-2.6^{*}$ & 1.3 & 4.5 & $2.8^{* *}$ \\
\hline Poterium sanguisorba & 10.4 & 17.9 & $2.6^{*}$ & 20.3 & 17.9 & -0.8 & 10.4 & 20.3 & $4.4 * * *$ \\
\hline
\end{tabular}


Table 1 continued

\begin{tabular}{|c|c|c|c|c|c|c|c|c|c|}
\hline & \multicolumn{2}{|c|}{$\begin{array}{l}\text { Teph. present/ } \\
\text { absent }\end{array}$} & \multirow[t]{2}{*}{$T$} & \multicolumn{2}{|c|}{$\begin{array}{l}\text { Teph. present/ } \\
\text { absent }\end{array}$} & \multirow[t]{2}{*}{$T$} & \multicolumn{2}{|c|}{$\begin{array}{l}\text { Teph. present/ } \\
\text { present }\end{array}$} & \multirow[t]{2}{*}{$T$} \\
\hline & $1967 p$ & $2016 \mathrm{a}$ & & $2016 p$ & $2016 \mathrm{a}$ & & $1967 p$ & $2016 p$ & \\
\hline Primula veris & 3.3 & 7.6 & 1.9 & 4.9 & 7.6 & 0.9 & 3.3 & 4.9 & 0.9 \\
\hline Prunella vulgaris & 4.8 & 3.7 & -0.6 & 2.4 & 3.7 & 0.7 & 4.8 & 2.4 & -1.7 \\
\hline Ranunculus bulbosus & 3.0 & 10.2 & $3.4 * *$ & 7.9 & 10.2 & 0.8 & 3.0 & 7.9 & $2.7 * *$ \\
\hline Scabiosa columbaria & 4.6 & 0.7 & $-2.8 * *$ & 2.9 & 0.7 & -2.0 & 4.6 & 2.9 & -1.2 \\
\hline Succisa pratensis & 4.0 & 3.6 & -0.1 & 7.9 & 3.6 & -1.2 & 4.0 & 7.9 & 1.3 \\
\hline Taraxacum agg. & 0.2 & 1.9 & $3.8 * * *$ & 0.5 & 1.9 & $2.3^{*}$ & 0.2 & 0.5 & 1.0 \\
\hline Thymus polytrichus & 2.3 & 2.4 & 0.1 & 12.1 & 2.4 & $-4.6 * * *$ & 2.3 & 12.1 & $6.3 * * *$ \\
\hline
\end{tabular}

$* P<0.05$, ** $P<0.01$, *** $P<0.001$. Species in bold occur in $>80 \%$ of quadrats; average percentage cover values are presented below. Species percentage cover data were arcsine transformed prior to analyses. 2016 indicates the 2014/2016 re-survey; $\mathrm{p}=$ Tephroseris present; $\mathrm{a}=$ Tephroseris absent

Fig. 3 Boxplots of coverweighted Ellenberg indicator values for nitrogen $(\mathrm{N})$, light $(\mathrm{L})$, reaction (R) and moisture (F) for plots in which $T$. integrifolia was present in the original 1967 survey, but absent in the 2014/2016 re-survey
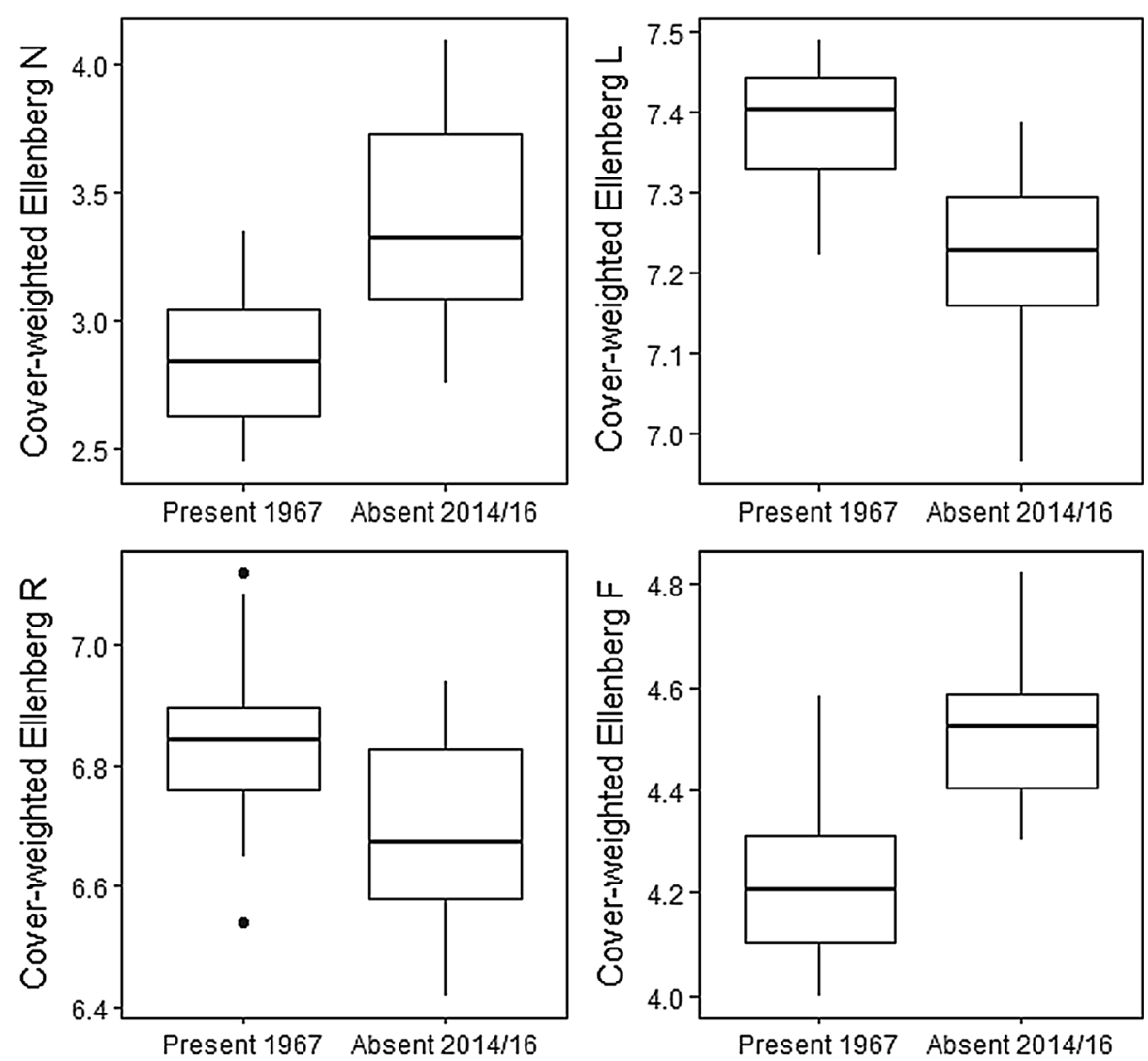

were grazed by sheep and/or cattle (and in one case by ponies) in the autumn and winter months, and with occasional periods of overgrazing in the past. All but one of the sites where $T$. integrifolia was absent had been grazed for the majority of time between the original and re-survey, but had either experienced a long period of neglect and an absence of livestock, or been undergrazed for an extended period of time. 
Fig. 4 Boxplots of coverweighted Ellenberg indicator values for nitrogen $(\mathrm{N})$, light $(\mathrm{L})$, reaction (R) and moisture (F) for plots where $T$. integrifolia was either present or absent in the 2014/2016 re-survey
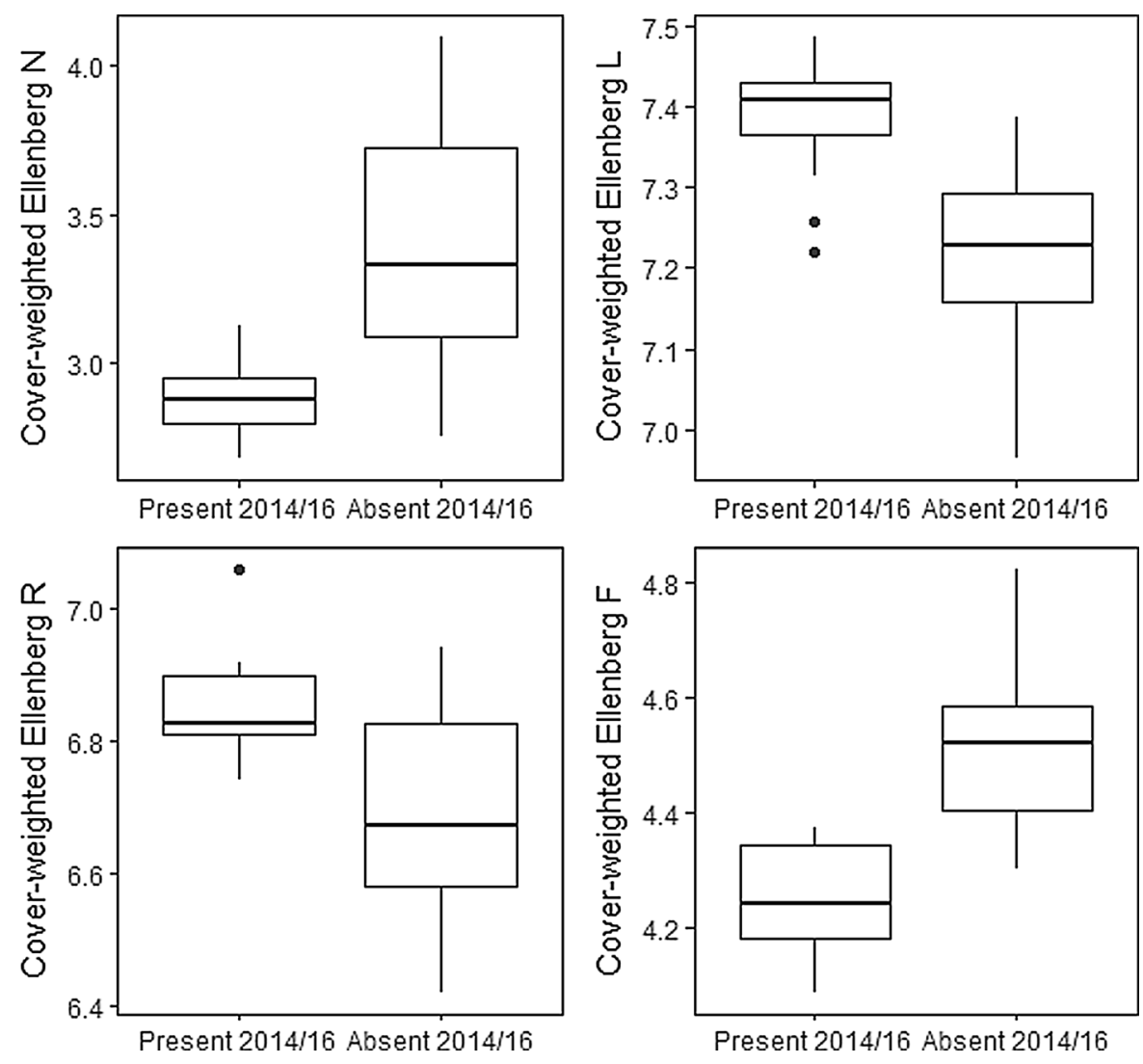

\section{Discussion}

Species richness

Our re-visitation study appears to support the observations of Bennie et al. (2006) with regard to the relative resilience of vegetation on steep south-facing turf over shallow rendzina soils, with little change overall in species richness noted across our study sites. Furthermore, we detected no significant temporal or spatial change in evenness or diversity, and these results do not appear to have been affected to any great extent by pseudo-turnover. Our results are consistent with other investigations that have reported a similar lack of change, or even increases, in species richness over decadal timeframes within calcareous grasslands (e.g. Sketch 1995; Partzsch 2000; Newton et al. 2012).

Bennie et al. (2006) speculated that vegetation change detected for deeper chalk soils may be a result of several factors, including subtle changes at the site level to the timing of livestock grazing or fluctuating stocking rates, declining rabbit populations, temporary abandonment or undergrazing, and/or the effects of atmospheric nitrogen $(\mathrm{N})$ deposition. In a long-term study of calcareous grasslands in Germany, Diekmann et al. (2014) showed that species richness on grassland sites with a low natural supply of N (e.g. sites on steep south-facing slopes with thin soils) was maintained, even under increased levels of atmospheric $\mathrm{N}$ deposition, because such grasslands were co-limited both by phosphorus and by water to a much greater extent than N (see also Carroll et al. 2003; Phoenix et al. 2003; Maskell et al. 2010). They went on to hypothesise that the composition of calcareous grassland was more likely to be affected negatively by changes to management and land use, a view shared by both Wilson et al. (1995) and Jacquemyn et al. (2003) who found no and minimal effects, respectively, relating to $\mathrm{N}$ deposition, with grazing management viewed as the primary means of regulating the composition and diversity of chalk grassland. Van den Berg et al. (2011) found no correlation between $\mathrm{N}$ deposition and a change in Ellenberg $\mathrm{N}$ values, but did find that a decrease in grazing pressure was significantly negatively correlated to a change in diversity (see also Walker et al. 2009). 
Fig. 5 Boxplots of coverweighted Ellenberg indicator values for nitrogen $(\mathrm{N})$, light $(\mathrm{L})$, reaction $(\mathrm{R})$ and moisture $(\mathrm{F})$ for plots where $T$. integrifolia was present in both the original 1967 survey and the 2014/2016 re-survey
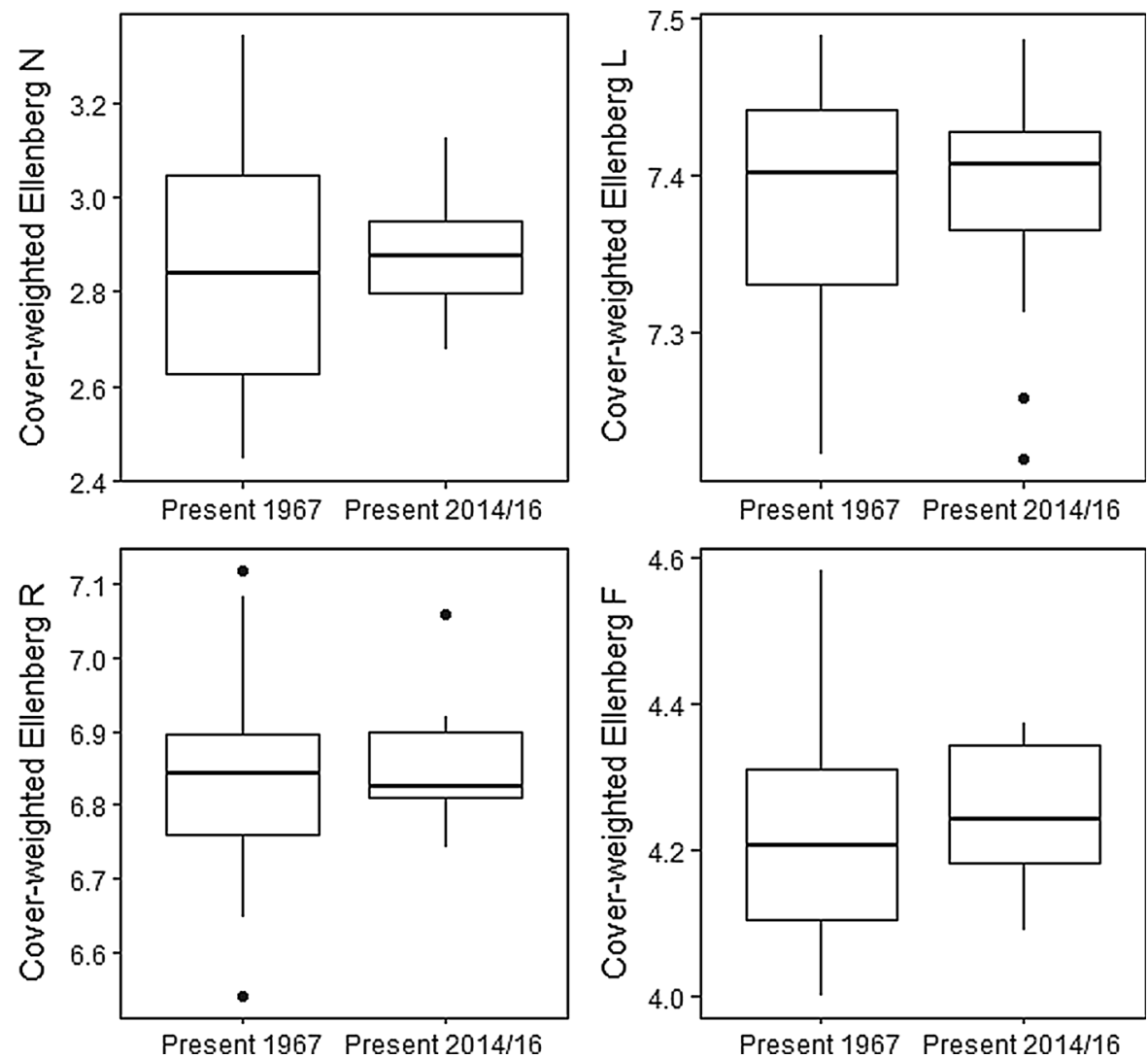

Species composition

Our findings revealed a significant alteration in vegetation composition at sites where $T$. integrifolia had been lost, as shown by an increase in Ellenberg fertility and moisture signifying nutrient enrichment, and a decrease in the cover of low-growing, lightdemanding dry grassland specialists. At plots where $T$. integrifolia was retained, there was no marked shift in the prevailing environmental conditions, but here too there were clear increases in cover for many of the species that had also spread in plots where $T$. integrifolia was absent, and in particular Bromopsis erecta, Carex flacca, Poterium sanguisorba and Ranunculus bulbosus. This suggests an underlying issue, albeit much more prevalent at plots where $T$. integrifolia was absent, which, when seen in the context of the available management data, would seem to be associated predominantly with grazing (see also Stevens et al. 2016).

At sites that had lost communities of the type in which T. integrifolia is normally found, as defined by the commonly used British National Vegetation
Classification (NVC; Rodwell 1992), vegetation would appear to have shifted from a relatively even cover of Avenula pratensis, Briza media, Bromopsis erecta and Koeleria macrantha in the 1960s, recognisable as NVC community type CG2 Festuca ovina-Avenula pratensis grassland, to a threefold increase in the cover of $B$. erecta but with relative stability in the cover of the other three grasses, equating with a comparatively coarser CG3 $B$. erecta sward. Bromopsis erecta has been demonstrated to restrict the growth of the surrounding species gradually by generating high vertical 'shoot thrust' (Campbell et al. 1992) and by overtopping lower-growing species, reducing available light and radiation (Mitchley and Willems 1995). Plants of B. erecta also produce large quantities of leaf litter that is resistant to being broken down by other organisms. However, it is a palatable grass readily weakened by grazing (Ellenberg 1988), particularly if grazing is undertaken in the period of most rapid growth. A cutting experiment by Wells (1971) at Knocking Hoe NNR in Bedfordshire demonstrated that cutting a sward dominated by $B$. erecta in May, June and July reduced its competitive 
power without adversely affecting other species. Walker and Pinches (2011) found that winter grazing or a combination of winter and summer/autumn grazing at low intensities, in combination with yearround rabbit grazing, led to a decline in the cover of $B$. erecta.

\section{Grazing management}

Communication with land managers and staff responsible for the maintenance of the SSSIs we visited for our survey confirmed that grazing with sheep, cattle, rabbits or combinations thereof has been sustained for many years on the majority of sites, albeit with variations in the timing and intensity of livestock grazing. Wells (1969) commented that a lack of grazing for more than ten years would lead to the loss of many characteristic chalk perennials, some of which would not re-establish even if grazing was later reinstated. This is especially true of short-lived rosette or semi-rosette perennials that have little or no seed bank, such as T. integrifolia (Widén 1987). Conversely, overgrazing, noted in the past at many plots that have retained $T$. integrifolia, prevents species from flowering but rarely causes a reduction in the total number of plant species present in an area and, when the grazing pressure is eased, these species are able to flower and reproduce. Studies by Lennartsson and Svensson (1996) and Lennartsson and Oostermeijer (2001) on Gentianella campestris, a biennial hemicryptophyte with a transient seed bank, showed that plants can cope with short periods of overgrazing via compensatory seed production after damage, but undergrazing led to a dominance of rank vegetation, restricted opportunities for both seedling survival and regeneration and the eventual loss of the species. Whilst there was evidence of contemporary grazing at all our plots, where $T$. integrifolia had been lost, this was almost always associated with extended periods since 1970 when livestock grazing was either absent or much reduced. This would appear to have led to the loss of the species but, following the reinstatement of grazing at a later date, plots recovered to support a diverse if more mesotrophic flora. The correlation between a past lack of grazing or undergrazing and the loss of $T$. integrifolia populations has also been reported in Walker et al. (2017) following the analysis of a targeted survey undertaken at twenty-six sites across the chalk of lowland England.
At one of the most species-rich plots retaining $T$. integrifolia, there was a mixed grazing regime consisting of summer grazing at a low stocking density by cattle (White Park and, more recently, Gloucester), followed by sheep (Wiltshire Horn) and cattle in the winter months. However, nearby grassland of similar aspect and soil type which did not retain $T$. integrifolia was extensively winter grazed only, with summer grazing by cattle ceasing in the 1990s. In a precursor to the findings of Bennie et al. (2006), an investigation by Hawes (1971) into the effects of seasonal grazing at two species-rich calcareous grassland sites in lowland England found that vegetation on the upper slopes on shallow rendzina soils was more stable than on the lower slopes with deeper soils, and furthermore whilst autumn or winter grazing over three years maintained structure, spring and summer grazing improved structure by reducing sward height and leaf litter. The author recommended a rotational system of grazing, to include all seasons but also with periods of no grazing to benefit local fauna (see also Woodcock et al. 2005). However, a re-survey by Hawes four decades after the original survey reported a significant grazing deficit over time in the spring and early summer and a much increased cover of $B$. erecta, and the decline of $A$. pratensis and $K$. macrantha (Hawes 2015).

Livestock are now often excluded from sites of high nature conservation during the spring and summer months, perhaps in part due to prescriptions for the management of calcareous grassland on SSSIs that recommend a cessation of livestock grazing throughout most of the flowering and fruiting period (Anon. 2013). Wells (1976) recommended a stocking density of three sheep/0.4 ha for the grazing of chalk downland, to produce a sward height of ca $5 \mathrm{~cm}$ by the end of the growing season, but grazing management can be complex, particularly for sites rich in flora and fauna, and at least two of the study sites where $T$. integrifolia was absent support nationally important populations of the butterflies Euphydryas aurinia and Hamearis lucina, both of which require a taller sward than is optimal for $T$. integrifolia and other low-growing hemicryptophytes (Turner et al. 2009; Smee et al. 2011).

\section{Conclusion}

All our study plots except for two were within SSSIs and all plots retained diverse, herb-rich vegetation. 
This is in contrast with re-visitation surveys by Bennie et al. (2006) and Newton et al. (2012) that reported a substantial loss of calcareous grassland sites after the periods of 50 and 70 years, respectively, and amply illustrates the value of statutory site protection in the mid-late 20th century. However, there were clear shifts in the composition of calcareous grassland vegetation to a coarser, slightly mesotrophic flora in areas that were considered to be relatively resilient to change, most notably in plots where $T$. integrifolia was absent.

It is most probable that the changes we detected were a result of modifications (intentional and unintentional) to grazing management over the past 50 years and, in particular, fluctuations in the timing and the duration of livestock grazing, as well as numbers of rabbits. We do not rule out the possibility that atmospheric $\mathrm{N}$ deposition may have also contributed to some of the changes noted in our revisitation study, but the literature would suggest that this plays a relatively minor role at sites with thin, well-buffered calcareous soils. A comparison of contemporary soil samples with those taken in the 1960s would have been extremely useful but, unfortunately, we were not able to source this historical information, and it most likely does not exist for most of the sites in our survey.

Whereas in the mid-20th century the greatest threat to calcareous grassland was direct habitat loss, undergrazing or temporary neglect would now appear to pose the principal threat, and particularly for sites that are fragmented and logistically difficult to graze. Recommendations concerning grazing times and stocking rates will in part depend upon other features of interest at the site level (e.g. Poschlod and Wallis DeVries 2002; Woodcock et al. 2005) as well as seasonal variations in vegetation growth in any one year related to climate, but our study highlights the necessity for an approach to management that prioritises integrated grazing management based on regular monitoring and assessment. This can be aided by the monitoring of distinctive, readily identifiable species such as $T$. integrifolia that have a marked sensitivity to habitat change, providing a potentially useful tool for the rapid assessment and monitoring of site quality. Focussing routine monitoring on such species allows non-expert observers to recognise the early stages of habitat degradation providing, in effect, a "health check" on individual sites and groups of sites. More rigorous specialist habitat assessment may then be applied as necessary.

Acknowledgements We would like to thank all the landowners who generously allowed us access to survey and thank Natural England and National Trust staff for providing information on grazing regimes.

Open Access This article is distributed under the terms of the Creative Commons Attribution 4.0 International License (http:// creativecommons.org/licenses/by/4.0/), which permits unrestricted use, distribution, and reproduction in any medium, provided you give appropriate credit to the original author(s) and the source, provide a link to the Creative Commons license, and indicate if changes were made.

\section{References}

Adriaens D, Honnay O, Hermy M (2006) No evidence of a plant extinction debt in highly fragmented calcareous grasslands in Belgium. Biol Cons 133:212-224

Anon (2013) Higher level stewardship environmental stewardship handbook fourth edition-January 2013. Natural England, Peterborough

Bennie J, Hill MO, Baxter R, Huntley B (2006) Influence of slope and aspect on long-term vegetation change in British chalk grasslands. J Ecol 94:355-368

Bobbink R, Willems JH (1987) Increasing dominance of Brachypodium pinnatum (L.) Beauv. in chalk grasslands: a threat to a species-rich ecosystem. Biol Conserv 40:301-314

Campbell BD, Grime JP, Mackey JML (1992) Shoot thrust and its role in plant competition. J Ecol 80:633-641

Carroll JA, Caporn SJM, Johnson D, Morecroft MD, Lee JA (2003) The interactions between plant growth, vegetation structure and soil processes in semi-natural acidic and calcareous grasslands receiving long-term inputs of simulated pollutant nitrogen deposition. Environ Pollut 121:363-376

Critchley CNR, Burke MJW, Stevens DP (2003) Conservation of lowland semi-natural grasslands in the UK: a review of botanical monitoring results from agri-environment schemes. Biol Conserv 115:263-278

Currall JEP (1987) A transformation of the Domin scale. Vegetatio 72:81-97

Diekmann M, Jandt U, Alard D, Bleeker A, Corcket E, Gowing DJG, Stevens CJ, Duprè C (2014) Long-term changes in calcareous grassland vegetation in North-western Germany-no decline in species richness, but a shift in species composition. Biol Conserv 172:170-179

Ellenberg H (1988) Vegetation ecology of Central Europe. Cambridge University Press, Cambridge

Farrell L (2009) Obituaries: Terrence (Terry) Charles Ernest Wells 1935-2008. Watsonia 27:277-282

Fenner, M (1975) Factors limiting the distribution of strict calcicoles. Unpublished Ph.D. thesis, University of Cambridge, Cambridge 
Fischer M, Stöcklin J (1997) Local extinctions of plants in remnants of extensively used calcareous grasslands 1950-1985. Conserv Biol 11:727-737

Fuller RM (1987) The changing extent and conservation interest of lowland grasslands in England and Wales: a review of grassland surveys 1930-84. Biol Conserv 40:281-300

Hawes PTJ (1971) Changes in the botanical composition of chalk grassland resulting from dietary selection by sheep. M.Phil. Thesis, Council for National Academic Awards, London

Hawes PTJ (2015) Sheep grazing and the management of chalk grassland. Br Wildl 27:25-30

Hill MO, Preston CD, Roy DB (2004) PLANTATT: attributes of British and Irish plants: status, size, life history, geography and habitats for use in connection with the New atlas of the British and Irish flora. Centre for Ecology and Hydrology, Peterborough

Hodgson JG, Grime JP, Wilson PJ, Thompson K, Band SR (2005) The impacts of agricultural change (1963-2003) on the grassland flora of Central England: processes and prospects. Basic Appl Ecol 6:107-118

Jacquemyn H, Brys R, Hermy M (2003) Short-term effects of different management regimes on the response of calcareous grassland vegetation to increased nitrogen. Biol Conserv 111:137-147

JNCC (2004) Common standards monitoring guidance for lowland grassland habitats. Joint Nature Conservation Committee, Peterborough

Kahmen S, Poschlod P, Schreiber K-F (2002) Conservation management of calcareous grasslands. Changes in plant species composition and response of functional traits during 25 years. Biol Conserv 104:319-328

Keymer RJ, Leach SJ (1990) Calcareous grassland - a limited resource in Britain. In: Hillier SH, Walton DHW, Wells DA (eds) Calcareous grasslands: ecology and management. Bluntisham Books, Bluntisham, pp 11-17

Lennartsson T, Oostermeijer JGB (2001) Demographic variation and population viability in Gentianella campestris: effects of grassland management and environmental stochasticity. J Ecol 89:451-463

Lennartsson T, Svensson R (1996) Patterns in the decline of three species of Gentianella in Sweden illustrating the deterioration of semi-natural grasslands. Symb Bot Ups 31:169-184

Maskell LC, Smart SM, Bullock JM, Thompson K, Stevens CJ (2010) Nitrogen deposition causes widespread loss of speciesrichness in British habitats. Glob Change Biol 16:671-679

Mitchley J, Willems JH (1995) Vertical canopy structure of Dutch chalk grasslands in relation to their management. Vegetatio 117:17-27

Newton AC, Walls RM, Golicher D, Keith SA, Diaz A, Bullock JM (2012) Structure, composition and dynamics of a calcareous grassland meta-community over a 70-year interval. J Ecol 100:196-209

Partzsch M (2000) Die Porphyrkuppenlandschaft des unteren Saaletals-Strukturwandel ihrer Vegetation in den letzten vier Jahrzehnten. Tuexenia 20:153-187

Phoenix GK, Booth RE, Leake JR, Read DJ, Grime JP, Lee JA (2003) Effects of enhanced nitrogen deposition and phosphorus limitation on nitrogen budgets of semi-natural grasslands. Glob Change Biol 9:1309-1321
Polus E, Vandewoestijne S, Choutt J, Baguette M (2007) Tracking the effects of one century of habitat loss and fragmentation on calcareous grassland butterfly communities. Biodivers Conserv 16:3423-3436

Poschlod P, Wallis DeVries MF (2002) The historical and socioeconomic perspective of calcareous grasslands-lessons from the distant and recent past. Biol Conserv 104:361-376

Preston CD, Pearman DA, Dines TD (eds) (2002) New atlas of the British and Irish flora. Oxford University Press, Oxford

Pykälä J, Luoto M, Heikkinen RK, Kontula T (2005) Plant species richness and persistence of rare plants in abandoned semi-natural grasslands in northern Europe. Basic Appl Ecol 6:25-33

Rodwell JS (1992) British plant communities. Volume 3. Grasslands and montane communities. Cambridge University Press, Cambridge

Ross LC, Woodin SJ, Hester AJ, Thompson DBA, Birks HJB (2010) How important is plot relocation accuracy when interpreting re-survey studies of vegetation change? Plant Ecol Divers 3:1-8

Sketch, C., 1995. National sample survey of lowland grasslands: pilot project. English Nature research reports no. 130. English Nature, Peterborough

Smee M, Smyth W, Tunmore M, Ffrench-Constant R, Hodgson D (2011) Butterflies on the brink: habitat requirements for declining populations of the marsh fritillary (Euphydryas aurinia) in SW England. J Insect Conserv 15:153-163

Smith UK (1979) Biological Flora of the British Isles: Senecio integrifolius (L.) Clairv. J Ecol 67:1109-1124

Stace CA (2010) New flora of the British Isles, 3rd edn. Cambridge University Press, Cambridge

Stevens CJ, Ceulemans T, Hodgson JG, Jarvis S, Grime JP, Smart SM (2016) Drivers of vegetation change in grasslands of the Sheffield region, northern England, between 1965 and 2012/13. Appl Veg Sci 19:187-195

Stroh PA (2016) Tephroseris integrifolia (L.) Holub subsp. integrifolia. Field Fleawort. Species Account. Botanical Society of Britain and Ireland (BSBI), Bristol. http://bsbi. org/species-accounts

Stroh PA, Leach SJ, August TA, Walker KJ, Pearman DA, Rumsey FJ, Harrower CA, Fay MF, Martin JP, Pankhurst T, Preston CD, Taylor I (2014) A vascular plant red list for England. Botanical Society of Britain and Ireland (BSBI), Bristol

Turner EC, Granroth HMV, Johnson HR, Lucas CBH, Thompson AM, Froy H, German RN, Holdgate R (2009) Habitat preference and dispersal of the Duke of Burgundy butterfly (Hamearis lucina) on an abandoned chalk quarry in Bedfordshire, UK. J Insect Conserv 13:475-486

Van den Berg LJL, Vergeer P, Rich TCG, Smart SM, Guest D, Ashmore MR (2011) Direct and indirect effects of nitrogen deposition on species composition change in calcareous grasslands. Glob Change Biol 17:1871-1883

Van Dijk G (1991) The status of semi-natural grasslands in Europe. In: Goriup PD, Batten LA, Norton JA (eds) The conservation of lowland dry grassland birds in Europe. Joint Nature Conservation Committee, Peterborough, pp 15-36

Van Swaay CAM (2002) The importance of calcareous grasslands for butterflies in Europe. Biol Conserv 104:315-318 
Walker KJ, Pinches CE (2011) Reduced grazing and the decline of Pulsatilla vulgaris Mill. (Ranunculaceae) in England, UK. Biol Conserv 144:3098-3105

Walker KJ, Preston CD, Boon CR (2009) Fifty years of change in an area of intensive agriculture: plant trait responses to habitat modification and conservation, Bedfordshire, England. Biodivers Conserv 18:3579-3613

Walker KJ, Stroh PA, Ellis RG (2017) Threatened Plants in Britain and Ireland: the results of a sample survey. Botanical Society of Britain and Ireland (BSBI), Bristol

Wells TCE (1968) Land use changes affecting Pulsatilla vulgaris in England. Biol Conserv 1:37-44

Wells TCE (1969) Botanical aspects of conservation management of chalk grasslands. Biol Conserv 2:36-44

Wells TCE (1971) A comparison of the effects of sheep grazing and mechanical cutting on the structure and botanical composition of chalk grassland. In: Duffey E, Watt AS (eds) The scientific management of animal and plant communities for conservation. Blackwell Scientific Publications, Oxford, pp 497-515

Wells TCE, Sheail J, Ball DF, Ward LK (1976) Ecological studies on the Porton Ranges: relationships between vegetation, soils and land-use history. J Ecol 1:589-626
Widén B (1987) Population biology of Senecio integrifolius (Compositae), a rare plant in Sweden. Nordic J Bot 7:687-704

Willems JH (1990) Calcareous grasslands in Continental Europe. In: Hillier SH, Walton DWH, Wells DA (eds) Calcareous grasslands: ecology and management. Bluntisham Books, Bluntisham, pp 3-10

Willems JH, Peet RK, Bik L (1993) Changes in chalk-grassland structure and species richness resulting from selective nutrient additions. J Veg Sci 4:203-212

Wilson EJ, Wells TCE, Sparks TH (1995) Are calcareous grasslands in the UK under threat from nitrogen deposition-an experimental determination of a critical load. J Ecol 83:823-832

Woodcock BA, Pywell R, Roy DB, Rose R, Bell D (2005) Grazing management of calcareous grasslands and its implications for the conservation of beetle communities. Biol Conserv 125:192-202 